\title{
The Essential Oil Compositions of Rosmarinus officinalis L. Cultivated in Konya and Collected from Mersin-Turkey
}

\author{
Yavuz BAĞCI*, Yüksel KAN², Süleyman DOĞU³, Sadiye Ayşe ÇELiK² \\ 1Department of Biology, Faculty of Science and Art, Selcuk University, Konya, TURKEY. \\ ${ }^{2}$ Department of Medicinal Plants, Agriculture Faculty, Selcuk University, 42049, Konya, TURKEY. \\ ${ }^{3}$ Department of Biology, Faculty of Education Meram, Necmettin Erbakan University, TR 42090 Konya, TURKEY.
}

\begin{abstract}
Purpose: In this research, essential oil (EO) compositions of the dried and fresh aerial parts of Rosmarinus officinalis cultivated in the reearch field in Selcuk University Medicinal and Aromatic Plants Department Area in Konya and collected from Mersin was investigated. Material and Methods: EO was distilled by using Clevenger type apparatus for $3 \mathrm{~h}$ and the chemical compositions were detected in GC-MS. Results: Although, the oil yields of the collected rosemary was determined to be $0.4 \mathrm{ml}$ (in fresh) and $0.6 \mathrm{ml}$ (in dried) aerial parts, the yields of the cultivated plants for fresh and dried parts were $0.32 \mathrm{ml}$ (in fresh) and $0.9 \mathrm{ml}$ (in dried), respectively. In this research the differences with respect to composition and components were determined between the cultivated and collected plants. On the other hand, in this study, it was also determined that the EO compositions varied with respect to be fresh or dry of the plant parts. While there were 67 and 55 of EO compositions were observed in the fresh and dried parts of the collected marjoram, respectively; in the cultivated plants there were 46 (in fresh) and 79 (in dried) components detected. Conclusion: In this study, it was observed that the major EO compositions were camphor, 1.8-cineole, borneol, $\alpha$-pinene, linalool, verbenone, bornyl acetate, limonene and camphene. The objective of the study to detect the differences between the EO compositions varied according to be the plant fresh or dry and collected or cultivated.
\end{abstract}

Key words: Rosemary, Rosmarinus officinalis, Oil yield, Essential oil composition, Camphor.

\section{INTRODUCTION}

Rosemary (Rosmarinus officinalis L.) is an important medicinal and aromatic plant from the family Lamiaceae, ${ }^{2}$ which is represented by different names such as Turkish bushard, hasalbal and akpüren. The rosemary plant is $50-100 \mathrm{~cm}$ high, with bushes appearing as a perennial plant ${ }^{3}$ (Photo 1). Rosemary, ${ }^{5}$ which grows wild in places where the Mediterranean climate dominates, has wide use in the world as a medical, aromatic and ornamental plant. In folk medicine, analgesic, anti-inflammatory and treatment of gastrointestinal disturbances are properties attributed to this species. ${ }^{8,9}$ It is located in the category of rosemary non-wood products which grow mostly in the southern and western coastal waters in Turkey. It has a production of 172 tons in 2014 and 758 tons in 2013. ${ }^{1}$ In addition, the fact that biberia is the only commercial plant in Europe and America where antioxidant use is offered ${ }^{4}$ emphasizes the necessity of breeding in our country.

The aim of the study to compare of differences between the essential oil (EO) compositions of the dried and fresh aerial parts of Rosmarinus officinalis cultivated in the
DOI: 10.5530/ijper.51.3s.69 Correspondence: Yavuz BAĞCl, Department of Biology, Faculty of Science and Art, Selcuk University, Konya, TURKEY

Phone no: +905334652169 Email Id : ybagci66@gmail. com

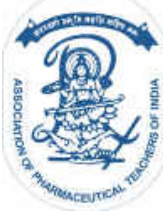

www.ijper.org 


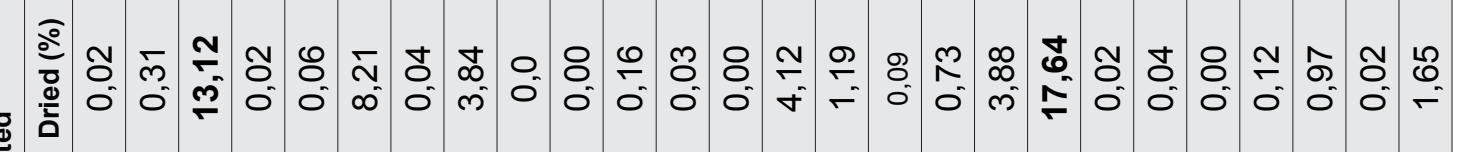

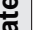
U.

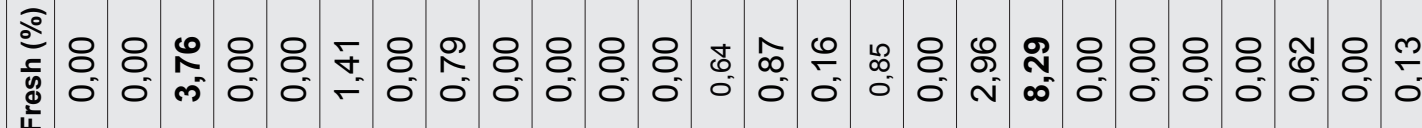

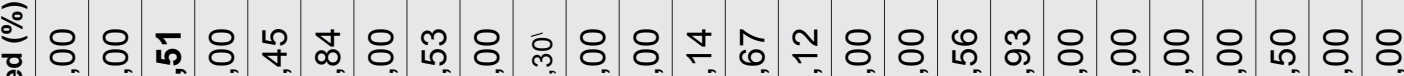
至

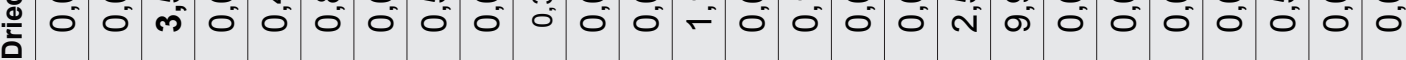

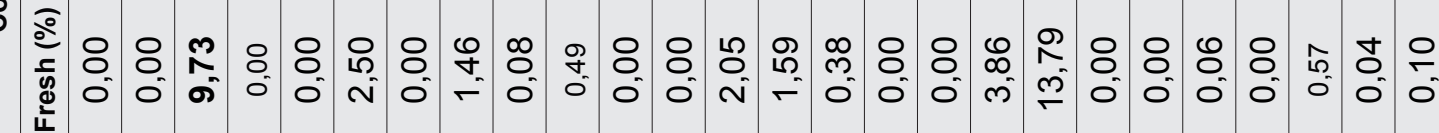

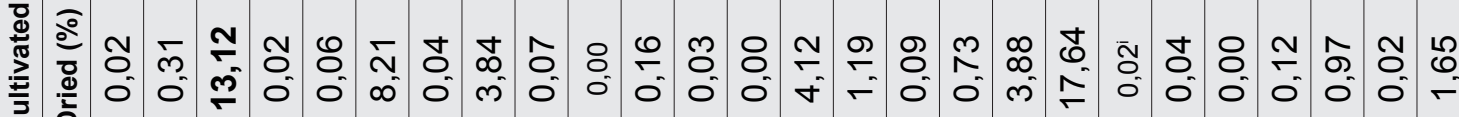

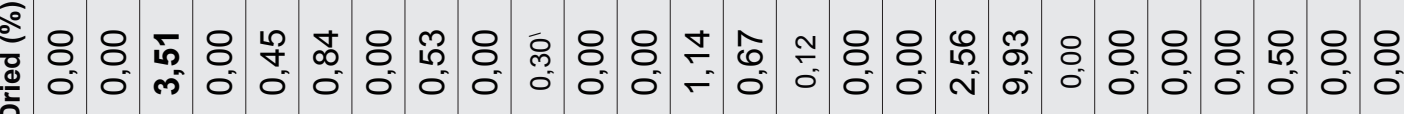
空

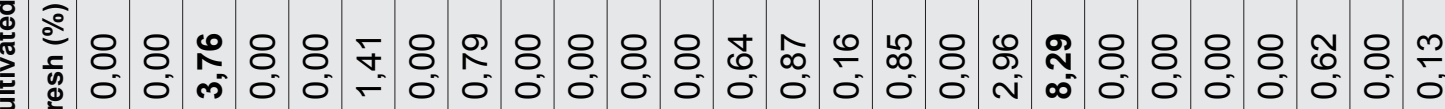
는

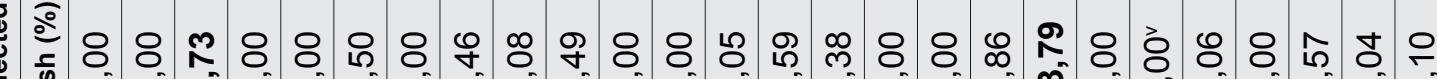

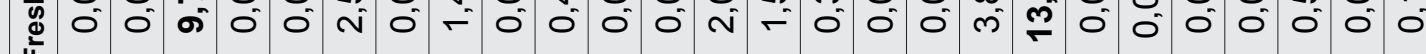

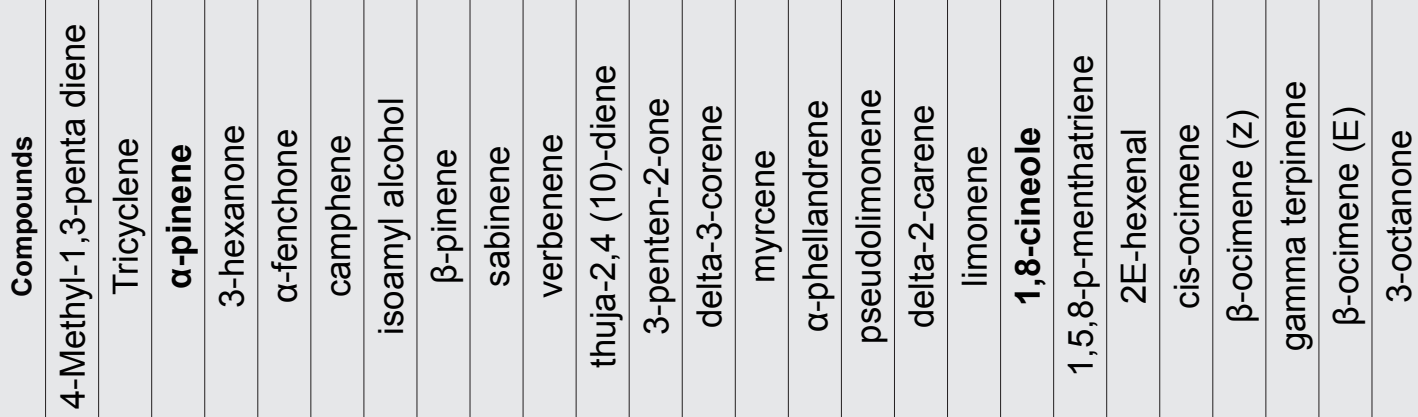

* 눙유유유

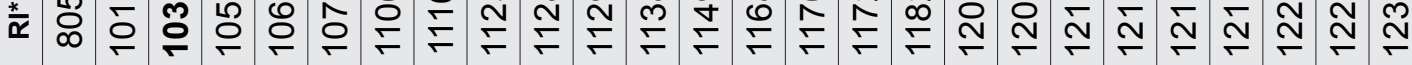




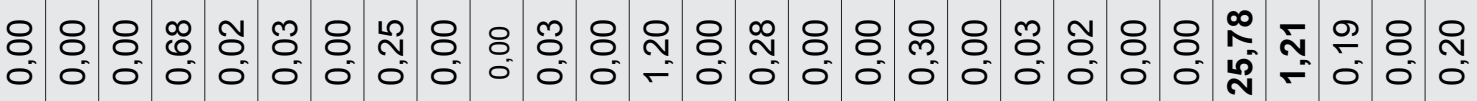

O

8.

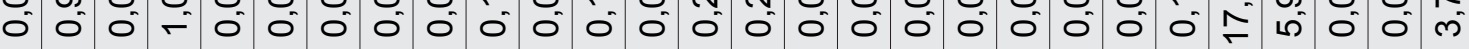
O 8 O

응ำ

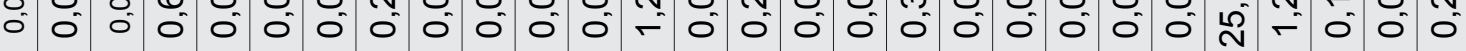

je

O

O

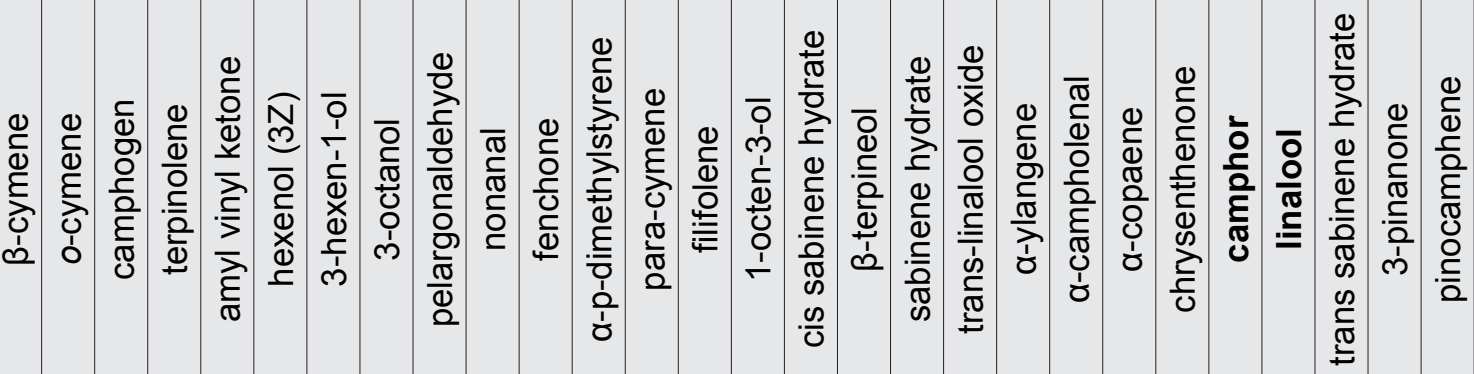

ఋ్లి

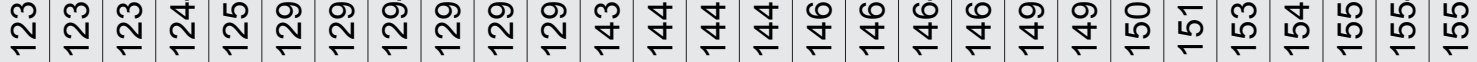




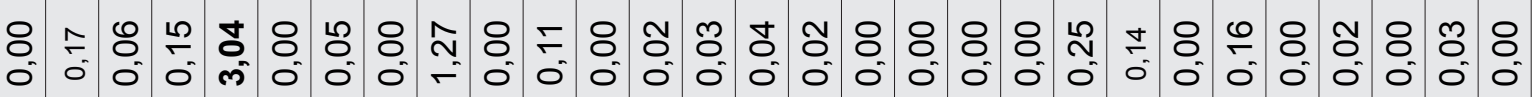

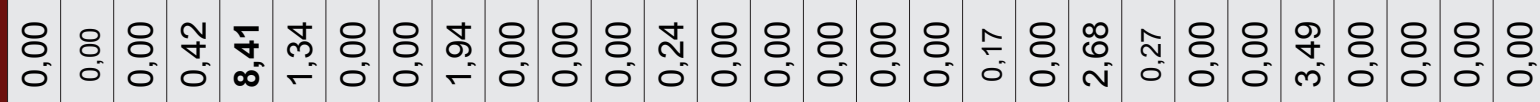

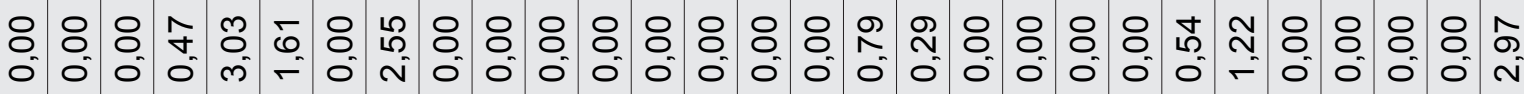

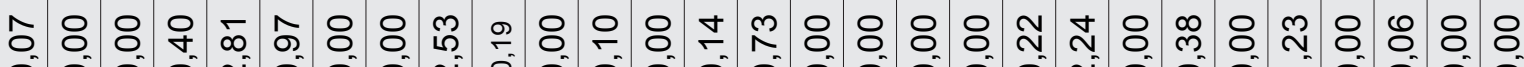

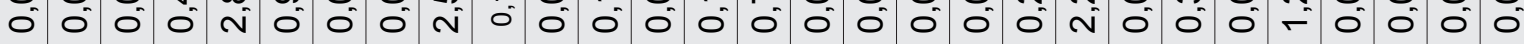

8ำ

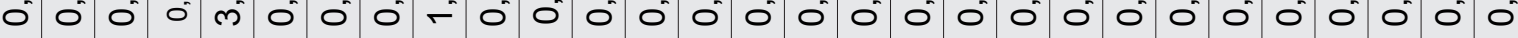

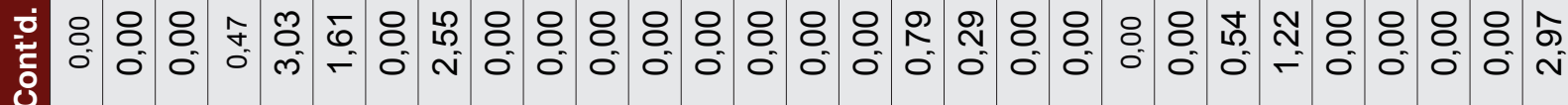

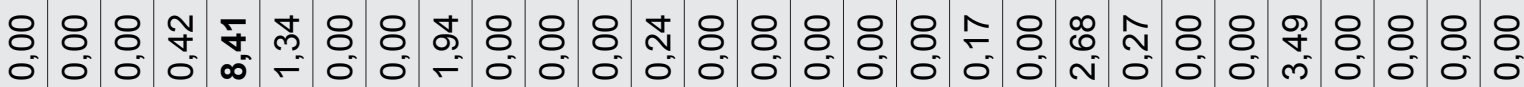

ㅇㅇㅎํ

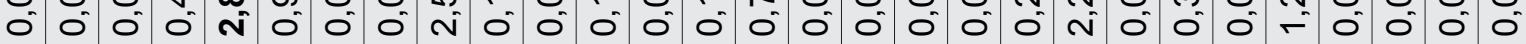

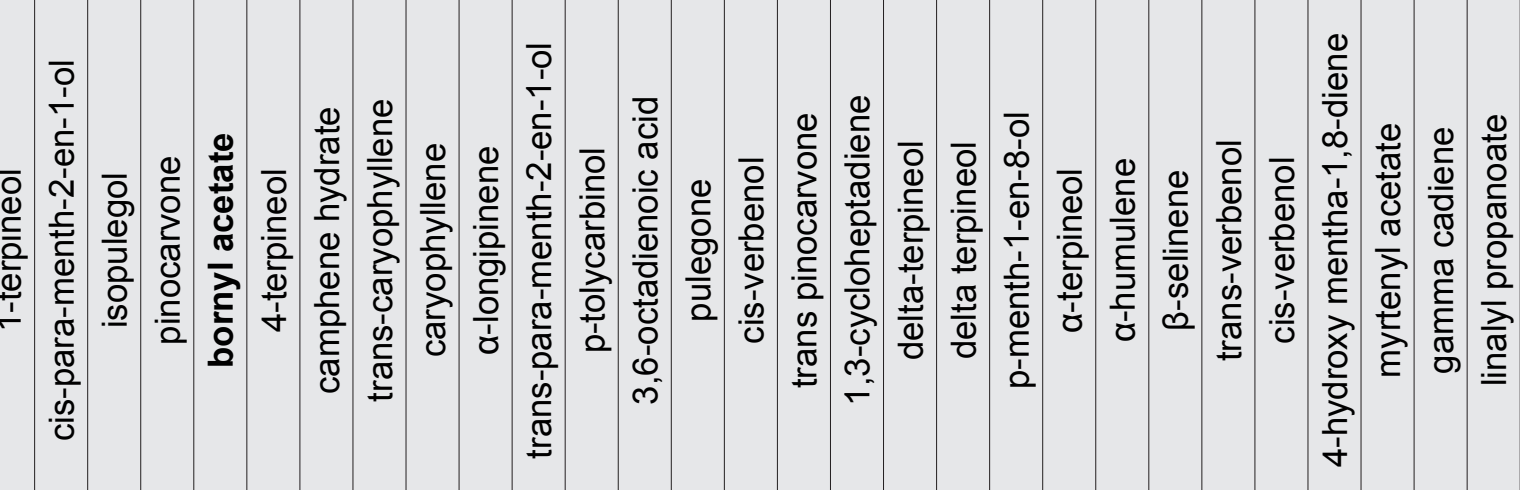

ஜ 뉸 


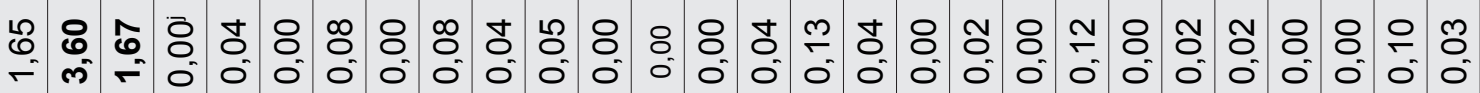

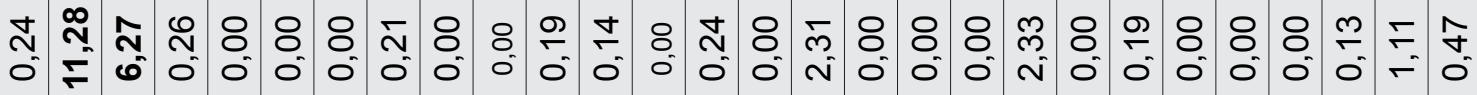

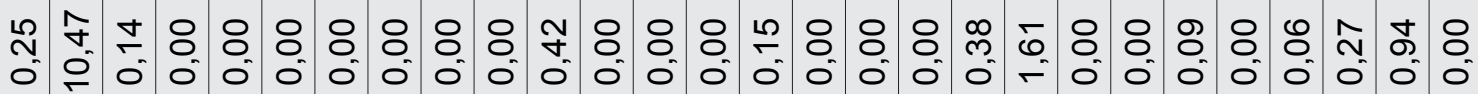

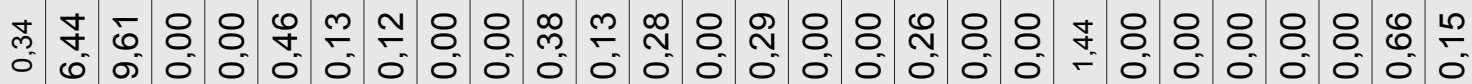

은

空

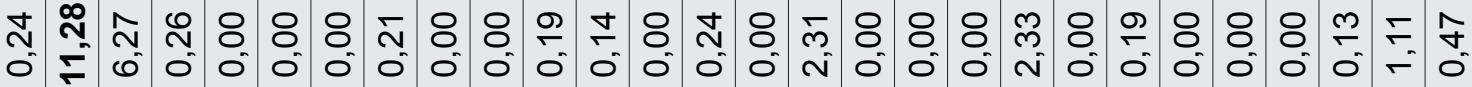

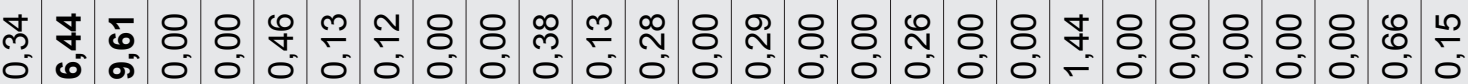

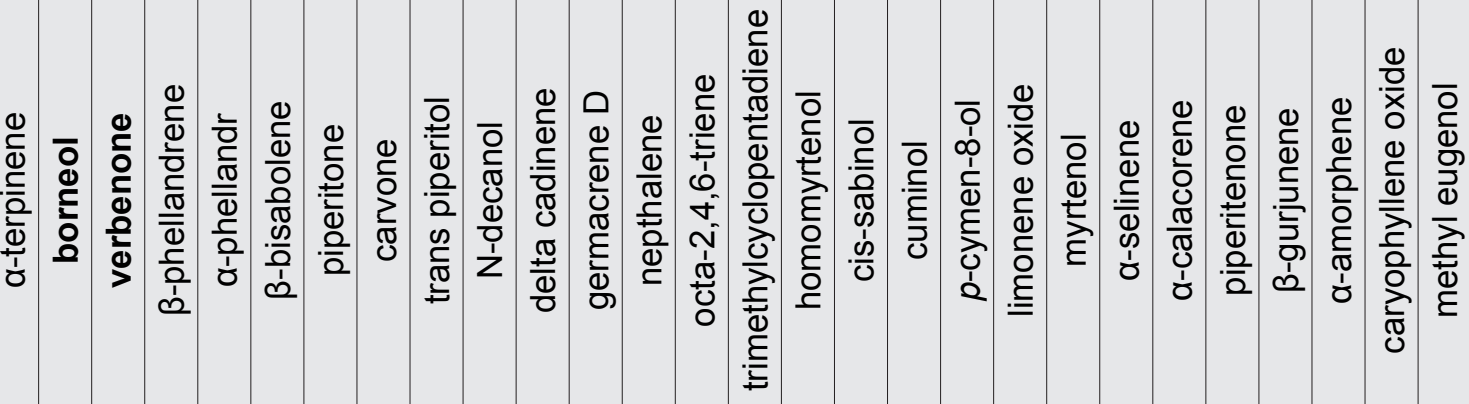

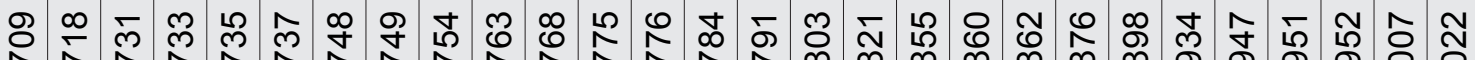

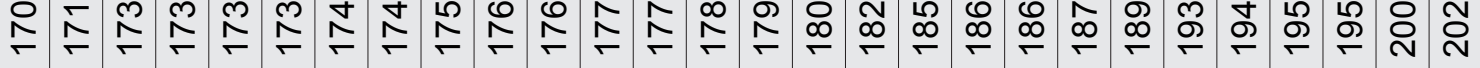




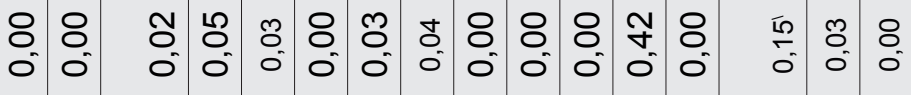
$\begin{array}{llll}8 & 8 & 0 & 8 \\ 0 & 0 & 0 & 0 \\ 0 & & 0\end{array}$

$\begin{array}{lllllllllllllll}0 & 0 & 0 & 0 & 0 & 0 & 0 & 0 & 0 & 0 & 0 & 0 & 0 & 0 & 0 \\ 0 & 0 & 0 & 0 & 0 & 0 & 0 & 0\end{array}$ $\therefore:-8:$

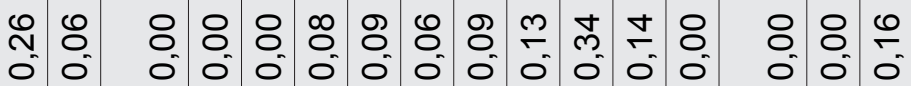
\begin{tabular}{llll}
8 & \multirow{1}{*}{} & 8 & 0 \\
0 & 0 & 0 & 0 \\
0 & 0 & 0
\end{tabular}

8 80 O $\begin{array}{llll}1 & 8 & 8 & 8 \\ 0 & 0 & 0 & 0\end{array}$

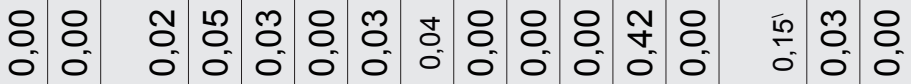
$\begin{array}{llll}8 & 8 & 8 & 0 \\ 0 & 0 & 0 & 0 \\ 0 & 0 & & 0\end{array}$

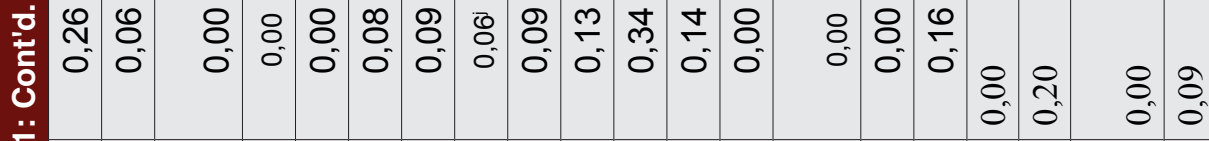

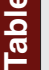

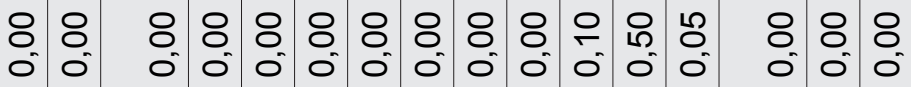
$\begin{array}{llll}8 & 8 & 8 & 8 \\ 0 & 0 & 0 & 0\end{array}$

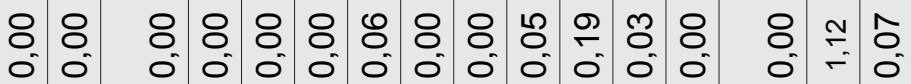

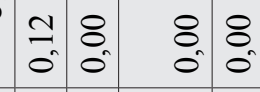

定

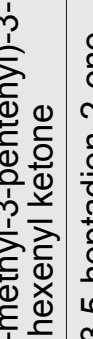

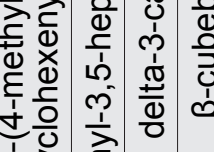
mं 定 ڤै

ஸ் ֻே

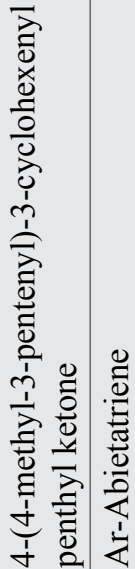

む゙ D্N 


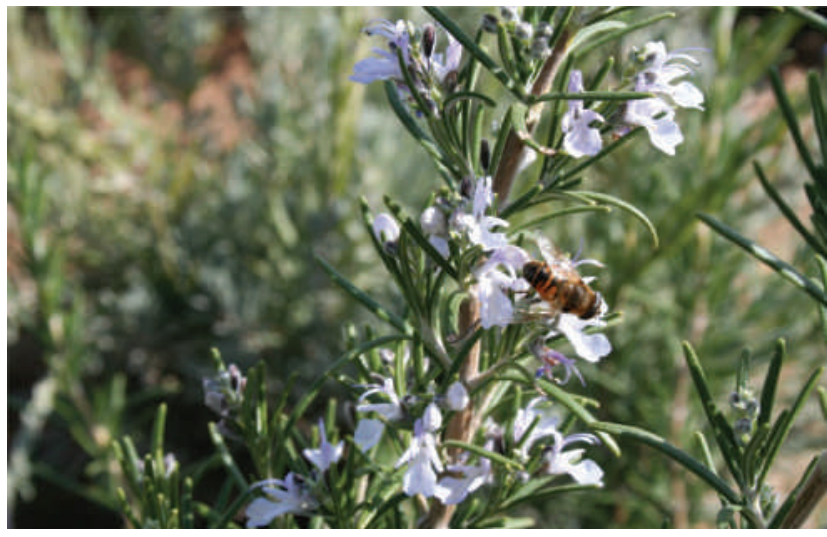

Photo 1: Rosmarinus officinalis flowers.

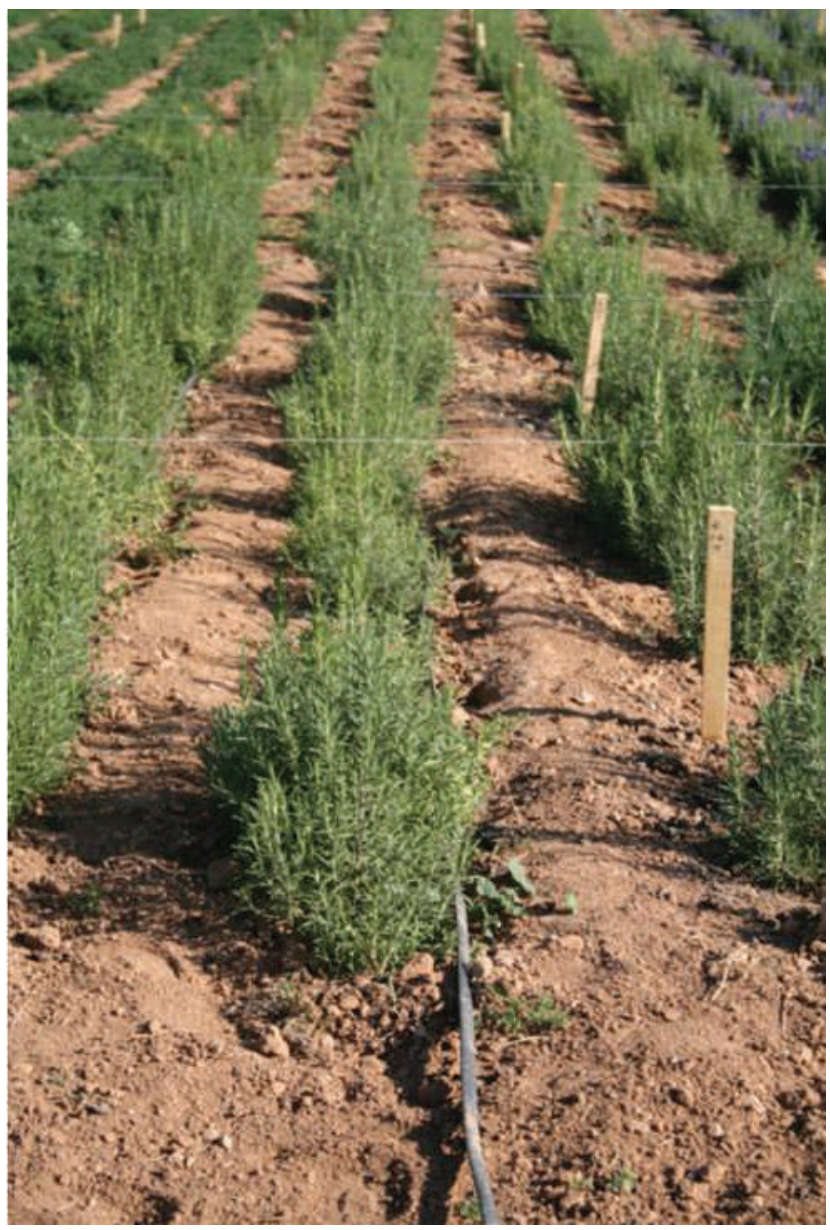

Photo 2: Rosmarinus officinalis general view

research field and collected from Mersin was investigated.

\section{MATERIAL AND METHODS \\ Materials}

Plant materials were collected in 2015 from Mersin and Selcuk University, Field Crops Department, Medical

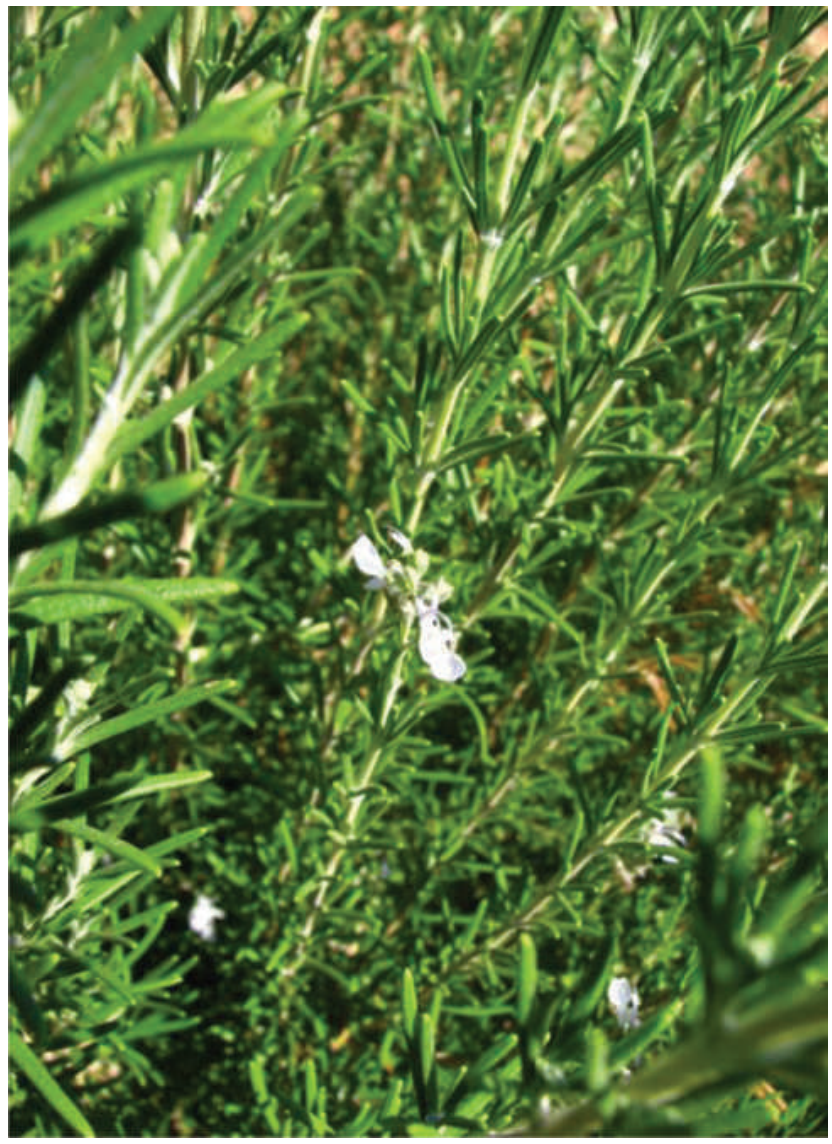

Photo 3: Rosmarinus officinalis flowers

Plant Garden. A voucher specimen has been deposited at the KNYA herbarium.

\section{Methods}

Dried and fresh aerial parts (branch, leaf and herb) of the collected and cultivated Rosmarinus officinalis were subjected to hydrodistillation for $3 \mathrm{~h}$ using Clevenger type apparatus to produce essential oil. The EOs were stored at $-20{ }^{\circ} \mathrm{C}$ until analyzed. The compositions of Rosmarinus officinalis L. (ROE), EOs were identified by The GC-MS analyses.

\section{RESULTS AND DISCUSSION}

As a result of the studies done, the volatile oil components of wet and dry specimens of Rosmarinus officinalis plant cultivated and from nature were compared (Table 1, Figure 1). Table 1 revelaed that there were significant $(p<0.01)$ differences between the dried and fresh aerial parts of the collected and cultivated Rosmarinus officinalis with respect to their EO compositions. While, the oil yields of the collected rosmarin was determined to be $0.4 \mathrm{ml}$ (in fresh) and $0.6 \mathrm{ml}$ (in dried) aerial parts, the yields of the cultivated plants for fresh and dried parts 


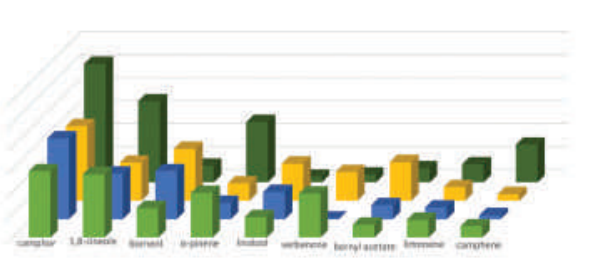

Figure 1: Total major essential oil compositions of the dried and fresh aerial parts of the collected and cultivated Rosmarinus officinalis

were $0.32 \mathrm{ml}$ (in fresh) and $0.9 \mathrm{ml}$ (in dried), respectively. Drying of the material made to increase the oil yield both in the collected and cultivated rosmarin. In dried materials, cultivation of the plant had positive effect on the yield. EO composition may vary considerably between aromatic plant species and varieties, and within the same variety from different enviromental areas. ${ }^{7}$ Besides EO yields, in this research the differences with respect to composition and components were determined between the cultivated and collected plants. On the other hand, in this study, it was determined that the EO compositions varied with respect to be fresh or dry of the plant parts. While there were 67 and 55 of EO compositions were observed in the fresh and dried parts of the collected rosemary, respectively; in the cultivated plants there were 46 (in fresh) and 79 (in dried) compositions detected. There were differences between the amounts of EO compositions of fresh and dried aerial parts of collected and cultivated rosmarin. Although the amounts of EO in the fresh collected rosmarin were higher than the those of cultivated, the rates of EO in dried collected material was lower than the those of cultivated.

According to Table 1, it was observed that the major EO compositions were camphor, 1,8-cineole, borneol, $\alpha$-pinene, linalool, verbenone, bornyl acetate, limonene and camphene. This compositions were also shown in Figure 1. Furthermore, in the other study, it was observed that the most abundant constituents documented for this oil are again $\alpha$-pinene, 1,8 -cineole, verbenone and camphor. ${ }^{6}$ Moreover, in a study, composition of Turkish rosemary and identified 20 compounds, with p-cymene (44\%), linalool (21\%), $\gamma$-terpinene (17\%), $\beta$-pinene (3.6\%), $\alpha$-pinene $(2.8 \%), 1,8$-cineole $(2.6 \%)$, and thymol (1.8\%) being the main constituents (20). Moreover, in the other study, it was determined that the major constituents of the oil were described as 1,8-cineole (27.23\%), $\alpha$-pinene
$(19.43 \%)$, camphor $(14.26 \%)$, camphene $(11.52 \%)$ and $\beta$-pinene $(6.71 \%)$.

\section{CONCLUSION}

The results of this study demonstrate that the aim of the study to compare of differences between the EO compounds and compositions varied according to be the plant fresh or dry and collected or cultivated. It was observed that camphor, and 1.8-cineole were the major EO contents.

\section{ACKNOWLEDGEMENT}

The authors are thankful for the technical helping to the University of Selcuk.

\section{CONFLICT OF INTEREST}

Authors declare that there is no conflict of interest.

\section{ABBREVIATONS USED}

EO: Essential oil; GC-MS: Gas Chromatography-Mass Spectrophotometry h: hours; ml: milliliter; ROE: Rosmarinus officinalis L. Essential oil; RI: Retention Indices.

\section{REFERENCES}

1. Aslan N, Baydar H, Kızıl S, Karık Ü, Şekeroğlu N ve Gümüşçü A. Tıbbi aromatik bitkiler üretiminde değişimler ve yeni arayışlar. VII, Türkiye Ziraat Mühendisliği Teknik Kong. Syf: 2015;483-507.

2. Begum A, Sandhya S, Shaffath SA, Vinod KR, Swapna R, Banji D. An indepth review on the medicinal flora Rosmarinus officinalis L. (Lamiaceae). Acta Sci Pol Technol Aliment. 2013;12(1):61-74.

3. Baytop T. Türkiye'de bitkilerle tedavi. İstanbul Üniversitesi Yayın No:3255, Ecz. Fak. Yayın No:40, İstanbul. 1984.

4. Bozin B, Mimica-Dukic N, Samojlik I, Jovin E. Antimicrobial and antioxidant properties pf rosemary and sage (Rosmarinus officinalis L. and Salvia officinalis L, Lamiaceae) essential oils. J. Agric. Food Chem. 2007;55(19):7879-85.

5. Ceylan A. Tıbbi bitkiler II. Ege Üniversitesi Yayın No. 1987;481.

6. Flamini G, Cioni PL, Morelli I, Macchia M, Ceccarini L. Main AgronomicProductive Characteristics of Two Ecotypes of Rosmarinus officinalis L. and Chemical Composition of Their Essential Oils. J Agric Food Chem. 2002;50(12):3512-7.

7. Zygadlo JA, Juliani HR. Study of essential oil composition of aromatic plants from Argentina. 2003;8;273-93. In: D.K. Majundar, J.N. Govil, and V.K. Singh (eds.), Recent progress in medicinal plants. Studium Press, Houston, TX.

8. Akbari J, Saeedi M, Farzin D, Morteza-Semnani K, Esmaili Z. Transdermal absorption enhancing effect of the essential oil of Rosmarinus officinalis on percutaneous absorption of $\mathrm{Na}$ diclofenac from topical gel. Pharm Biol 2015;53:1442-7.

9. Minaiyan M, Ghannadi AR, Afsharipour M, Mahzouni P. Effects of extract and essential oil of Rosmarinus officinalis L. on TNBS induced colitis in rats. Res Pharm Sci. 2011;6(1):13-21. 
PICTORIAL ABSTRACT
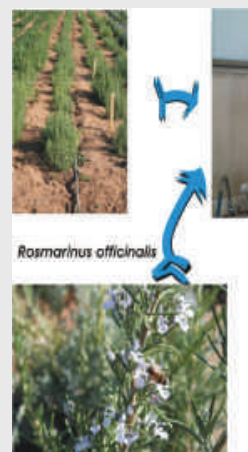

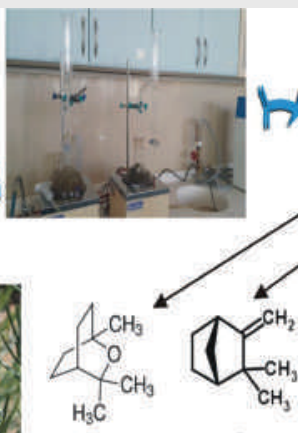

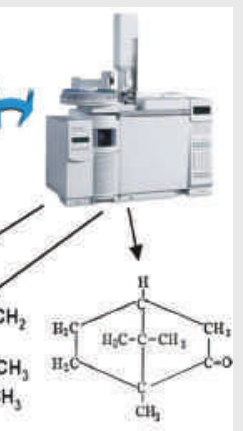

\section{ABOUT AUTHORS}

\section{SUMMARY}

- Rosemary (Rosmarinus officinalis L.) is an important medicinal and aromatic plant from the family Lamiaceae, which is represented by different names such as Turkish bushard, hasalbal and akpüren. In folk medicine, analgesic, anti-inflammatory and treatment of gastrointestinal disturbances are properties attributed to this species

- The aim of the study to compare of differences between the essential oil (EO) compositions of the dried and fresh aerial parts of Rosmarinus officinalis cultivated in the research field and collected from Mersin was investigated.

- Our study was observed that the major EO compositions were camphor, 1,8-cineole, borneol, $\alpha$-pinene, linalool, verbenone, bornyl acetate, limonene and camphene.

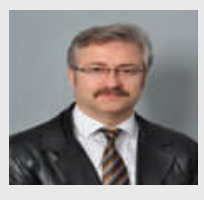

Prof. Dr. Yavuz BAGCl: He has completed his Ph. D. from Dept. of Biology, Selcuk University. His major research area and publications are Plant taxanomy, plant morphology, plant anatomy, palinology, ethnobotany, phytochemistry. He has published more than 50 research papers in international journals. He is presently working as Professor Dr. of Pharmaceutical Botany, Selcuk University Konya.

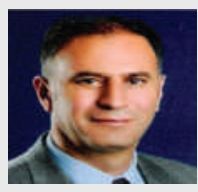

Prof. Dr. YükseL KAN: He is a researcher with 30 years experience working with medicinal and aromatic plants. Is presently working as Professor Department of Medicinal Plants, Faculty of Agriculture Selçuk University Konya, Turkey. He has published more than 80 research papers in International Journals.

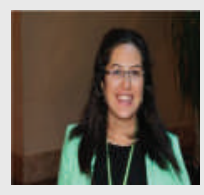

Ph.D. Expert S. Ayșe ÇELiK: She is working as Ph. D Expert, Department of Medicinal Plants since 2009, Faculty of Agriculture Selçuk University Konya, Turkey. Her research areas are medicinal and aromatic plants cultivation and their harvesting, seconder methabolites in medicinal plants, essential oil analysis, GC-MS analysis.

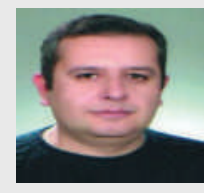

Ass. Prof. Dr. Süleyman Dogu: He is presently working as Assistant Professor, Department of Biology, Necmettin Erbakan University Konya, Turkey. His major research area and publications are Plant taxanomy, plant morphology, plant anatomy, palinology, ethnobotany, phytochemistry. He has published more than 40 research papers in International Journals.

Cite this article: BAGCI Y, KAN Y, DOGU S, ÇELIK SA. The Essential Oil Compositions of Rosmarinus officinalis L. Cultivated in Konya and Collected from Mersin-Turkey. Indian J of Pharmaceutical Education and Research. 2017;51(3)Suppl:S470-78. 